\title{
Managing the Energy-Efficient Development of the University: Restraints and Ways to Overcome Them*
}

\author{
Iryna M. SotnyK ${ }^{i}$, Mykola I. SotnyK ${ }^{i i}$, Alona A. Olondarii, \\ Natalita M. PIDOPRYhora ${ }^{i v}$, Mariana Yu. Maslit ${ }^{v}$
}

Recently, universities all over the world challenge the problem of reducing energy consumption through the introduction of energy efficient technologies. Higher educational institutions, especially in emerging and developing economies, often face significant barriers to achieving this goal. In developing countries, these obstacles are partly due to technical constraints. However, most of them belong to the organizational, economic, financial, social and educational ones, as is the case in emerging economies. This situation brings up to date the issues of identifying barriers to energy saving on university campuses as well as forming a set of organizational, economic and motivational measures for the energy saving potential implementation in higher educational institutions. On the example of Sumy State University (Ukraine), the study proves a crucial role of the initiative team of energy managers, the necessity of recognition and constant support of the university's energy efficient development by the topmanagement and wide involvement of teachers and students in energy saving activities. Creating a revolving energy efficiency fund at the university may significantly help to overcome the luck of investment and long-term payback of energy efficient and green energy technologies. In addition, both the promotion of the university's energy saving achievements by establishing effective communication with all stakeholders and the formation of a system of moral and economic incentives for energy saving essentially contribute to the successful development of energy efficiency policy of the educational institution. The experience of Sumy State University as a case study proves that a systematic approach to the organization of energy saving activities in the university campus based on the continuous improvement of management mechanisms allows achieving the goals of energy efficiency, even with many barriers.

Key words: barriers, energy consumption, energy efficiency, energy saving, management, policy, sustainable development, university.

Abbreviations:

EE - energy efficiency; ES - energy saving; SSU - Sumy State University.

УДК 332.8:338.27:378.1

JEL Codes: I25, O13, Q20, Q55

${ }^{i}$ Iryna M. Sotnyk, Dr. Sc. (Economics), Professor, Department of Economics, Entrepreneurship and BusinessAdministration, Sumy State University;

ii Mykola I. Sotnyk, Dr. Sc. (Tech.), Associate Professor, Department of Applied Hydro- and Aeromechanics, Sumy State University;

iii Alona A. Olondar, student of the Oleg Balatsky Academic and Research Institute of Finance, Economics and Management, Sumy State University;

iv Nataliia M. Pidopryhora, student of the Faculty of Technical Systems and Energy Efficient Technologies, Sumy State University;

Mariana Yu. Maslii, student of the Oleg Balatsky Academic and Research Institute of Finance, Economics and Management, Sumy State University.

* The paper has been supported by the Ministry of Education and Science of Ukraine under the research projects "Innovative management of energy-efficient and resource-saving technologies in Ukraine" (No. 0118U003571), "System model of efficiency management and forecasting of electricity use" (No. 0118U003583) and "Development of fundamental principles of reproduction mechanism of the social and economic development during the Third Industrial Revolution" (No. 0118U003578).

(C) I. M. Sotnyk, M. I. Sotnyk, A. A. Olondar, N. M. Pidopryhora, M. Yu. Maslii, 2020

https://doi.org/10.21272/mer.2020.89.06 
Iryna M. Sotnyk, Mykola I. Sotnyk, Alona A. Olondar, Nataliia M. Pidopryhora, Mariana Yu. Maslii. Managing the Energy-Efficient Development of the University: Restraints and Ways to Overcome Them

Introduction. Implementation of the sustainable development concept in the countries across the world involves paying significant attention to increasing energy efficiency (EE) of production and consumption processes, along with waste recycling, the use of environmentally sustainable transport, water conservation, environmental education, etc. [21, 22, 26, 31, 34]. The production and consumption processes have a significant impact on climate change, as the burning of fossil fuels for energy by convenient technologies is accompanied by the formation of greenhouse gases and other harmful substances that degrade the quality of the environment. In addition, the irrational use of fossil fuels leads to their overconsumption, which places an essential financial burden on consumers, worsening their economic and social well-being [4, $9,23]$.

According to estimates [1, 18, 25], 35-45\% of the energy produced in the world is consumed by buildings. The most energy-intensive processes are heating and air conditioning, lighting and electricity consumption by various appliances and equipment. It should be noted that among buildings the predominant share of energy consumption is in industrial sector and about $30-40 \%$ in the residential one $[1,10]$.

Compared to industrial facilities, university campuses consume, on average, less energy per unit area, but more than residential and some categories of administrative buildings. This is due to the fact that educational and scientific processes often involve powerful and energyintensive equipment for training and research, maintaining certain temperatures in the premises, sometimes special lighting, and so on. Part of the energy is also spent on the functioning of social and other infrastructure of educational institutions [1, 7, 12, 18]. Therefore, the systematic identification and implementation of reserves to reduce energy consumption by university buildings can considerably decrease energy costs, emissions of $\mathrm{CO}_{2}$ and other greenhouse gases into the atmosphere, contributing to sustainable development.

Today, the problem of rationalization of energy consumption is facing all universities in the world. The variety of functions performed by buildings on university campuses, work schedules and technical characteristics of facilities complicate the task of finding and implementing their energy saving (ES) potential, as often typical projects do not work here and require an individual approach. At the same time, there are many technical solutions on the market today that can meet any demand of universities in ES. The main problems are how to organize of the process of increasing EE in the educational institution, provoke interest of all stakeholders, select and implement an effective set of organizational, technical, financial and motivational measures that together will ensure the achievement of ES goals.

Problem statement. Works of many foreign (eg [1, 3, 7, 8, 14, 15, 17, 18, 19, 20, 25, 40, 48 ; 49]) and some domestic scientists (for example, [5, 6, 11, 13, 27, 28, 29, 30, 45]) are devoted to the research of organizational and technical, economic and financial as well as behavioral issues of ES and EE in higher educational institutions.

Thus, N. Maistry and T. M. McKay [20] analyze the features of energy consumption on the example of a South African university and identify barriers to promoting EE. Li-juan Qu et al. [17] consider mechanisms for forecasting energy needs for university buildings in China and propose strategies for EE management. Based on the identified significant differences in the energy consumption of university campuses depending on schools' discipline, nature and level, X. Zhou et al. [49] propose measures to implement their ES potential. Jiafang Song et al. [14] study the possibilities of reducing energy consumption on the example of the Tianjin Polytechnic University library building in China. A. Emeakaroha et al. [8] focus on the University of Kent, Canterbury campus, the UK, to study ES and carbon emission reduction strategies. Dong Woo Kim et al. [7] analyze the energy consumption present state of the major university campus of Korea to make the energy consumption reduction plan. I. M. Jomoah et 
І. М. Сотник, М. І. Сотник, А. А. Олондар, Н. М. Підопригора, М. Ю. Маслій.

Управління енергоефективним розвитком університету: бар'єри та шляхи їх подолання

al. [15] investigate the results of installation of an energy management system in the buildings of a typical university campus in Saudi Arabia and highlight the future trend in the implementation of this system in universities. D. Cotton et al. [3] explore differences between students' energy-related attitudes and reported behaviors, as well as their perceptions of their institution's ES efforts in two universities in the UK and one in Portugal in order to build strong ES policies for universities. J. Maiorano and B. Savan [19] investigate the barriers to the implementation of EE projects in Canadian universities, including access to capital, bounded rationality, hidden costs, imperfect information, risk and split incentives. They conclude that access to capital is the largest barrier to $\mathrm{EE}$ in university campuses.

Along with a large number of foreign publications concerning implementation of ES potential in higher educational institutions, these issues have only been partially researched by Ukrainian scientists. In particular, S. P. Denysyuk and O. V. Borychenko [5] substantiate the feasibility of developing and implementing a comprehensive integrated energy management system in domestic universities, emphasizing that energy management is a universal tool to increase the competitiveness of education institutions. S. V. Gajdukevych et al. [13] evaluate the technical and economic efficiency of the use of heat pump systems to maintain the microclimate in classrooms. V. M. Shulga and D. S. Khandoga [30] investigate the main causes of inefficient use of energy resources in universities and propose a set of organizational and technical measures to eliminate them. O. M. Pshinko et al. [28] identify promising areas for the implementation of ES potential on the example of a separate Ukrainian university. O. M. Pshinko et al. [27] create an optimization model for the formation of action plans to improve the efficiency of electricity consumption in a separate university campus and assess the expected economic effect of the implementation of such measures. In general, Ukrainian researchers consider only some aspects of the complex problem of ES in educational institutions. There is a lack of publications in the domestic scientific literature that offer a systematic view of the processes of organization and motivation of ES activities in higher educational institutions. This significantly slows down the realization of the potential for EE growth in Ukrainian universities.

The purpose of the research is to study restraints of the ES in domestic higher educational institutions and to form a set of managerial organizational, economic and motivational measures for the systematic realization of the potential for energy consumption rationalization in university campuses on the example of Sumy State University (SSU).

Results of the research. Modern suppliers of ES goods and services offer many technical solutions that can make higher educational institutions energy efficient. Leading European and American universities are clear examples of this. In particular, Wageningen University \& Research (Netherland), which took first place in UI GreenMetric World University Ranking in 2019, produces more green electricity than it consumes for its own needs [41, 47]. Thus, in $2018,106 \%$ of the energy consumed by the university was generated using sustainable methods. For 8 years (2010-2018) thanks to energy-efficient innovations the institution managed to reduce its $\mathrm{CO}_{2}$ footprint by $49 \%$. Many university buildings use the Heat and Cold Storage system for heating and air conditioning. Heat and cold are stored in a sand layer between 40 and 90 meters underground. In summer, the buildings are cooled with water pumped up from below and in winter, warm water is pumped up and is used for heating the ventilation air [47].

EE projects of the University of North Carolina (Chapel Hill, North Carolina, USA), which took first place among the 25 Top Green Schools in America in 2019, include construction of energy-efficient buildings, retrofitting more environmentally friendly hardware into older facilities, increasing green transportation options, and reducing water use. University of 
Iryna M. Sotnyk, Mykola I. Sotnyk, Alona A. Olondar, Nataliia M. Pidopryhora, Mariana Yu. Maslii. Managing the Energy-Efficient Development of the University: Restraints and Ways to Overcome Them

Massachusetts (Amherst, Massachusetts, USA) has an efficient recycling program and one of New England's largest solar panel projects [2]. In July 2017, the university and Eversource signed a three-year memorandum of understanding continuing their EE partnership with the goal of saving the university $\$ 1.8$ million in energy costs annually [42].

Despite the impressive results achieved in realizing the ES potential of higher educational institutions in the developed countries, many universities in emerging and developing economies face significant barriers to EE change. In particular, specific obstacles, distinctive for emerging and developing economies are technical limitations due to underdeveloped national and local energy infrastructure, low capacity of power grids, instability and unreliability of energy supply regimes, etc. [20, 24, 32, 33]. For emerging economies, these technical barriers are less relevant, as such countries tend to have extensive energy infrastructure. However, here the emphasis shifts to the issues of renewal and modernization of worn-out electrical, gas and heating networks, restoration and expansion of their capacity, etc. $[6,9,16,32]$.

Table 1

Main restraints to ES in university campuses [7, 19, 20, 25, 29, 30, 43, 44]

\begin{tabular}{|c|c|}
\hline $\begin{array}{c}\text { Group of } \\
\text { barriers }\end{array}$ & Restraints' description \\
\hline 1 & 2 \\
\hline Technical & $\begin{array}{l}\text { - low technology level of modern renewable energy facilities; } \\
\text { - obsolete university facilities including office and key energy equipment; } \\
-\quad \text { individual controlled air-conditioning system; } \\
- \text { centralized heating system; } \\
- \text { absence or lack of energy consumption meters at university facilities; } \\
-\quad \text { lack or inaccuracy of energy consumption data from meters; } \\
-\quad \text { absence or problems with the functioning of the automated energy metering system }\end{array}$ \\
\hline $\begin{array}{l}\text { Organiza- } \\
\text { tional }\end{array}$ & $\begin{array}{l}\text { - lack of ownership; } \\
\text { - decentralised decision-making; } \\
\text { - lack of in-house expertise and information on ES options in the educational institution for } \\
\text { making appropriate management decisions; } \\
\text { - non-recognition by the university management of the priority of ES activities; } \\
\text { - lack of long-term comprehensive ES strategies and tactical plans for their implementation, } \\
\text { agreed EE goals for different university divisions; } \\
\text { - lack of leadership within the sector, lack of initiative team of highly qualified energy } \\
\text { managers; } \\
\text { - lack or insufficient practice of involving university scientists in solving problems of } \\
\text { improving its EE, conducting research by students in this field; } \\
- \text { absence or problems with regulation and forecasting of energy consumption by university } \\
\text { facilities based on the data of the automated system of energy consumption metering; } \\
- \text { lack of an effective system of economic and moral incentives for ES activities at the } \\
\text { university, regulation of energy consumption, which provides interest in ES at the individual } \\
\text { level; } \\
\text { - poor system of communication with ES stakeholders and low level of their engagement in EE } \\
\text { projects; } \\
\text { - long-lasting procedures of purchases of the energy-efficient equipment, absence of } \\
\text { requirements of EE at purchase of other goods and services by university }\end{array}$ \\
\hline
\end{tabular}


І. М. Сотник, М. І. Сотник, А. А. Олондар, Н. М. Підопригора, М. Ю. Маслій.

Управління енергоефективним розвитком університету: бар'єри та шляхи їх подолання

\begin{tabular}{|c|c|}
\hline $\begin{array}{c}\text { Group of } \\
\text { barriers }\end{array}$ & Restraints' description \\
\hline 1 & 2 \\
\hline $\begin{array}{l}\text { Economic } \\
\text { and financial }\end{array}$ & $\begin{array}{l}\text { - lack of sufficient funds to invest in EE projects; } \\
\text { - other priorities for capital investment; } \\
\text { - too long payback period of renewable energy and EE facilities because of expensive initial } \\
\text { investment cost, lack of investment confidence; } \\
\text { - absence of a revolving EE fund at the university; } \\
\text { - giving preference to short-term ES measures over more effective long-term ones due to their } \\
\text { high risks and lack of investment; } \\
\text { - lack of financial resources for a decent salary for the team of energy managers and economic } \\
\text { incentives for university staff and students to save energy; } \\
\text { - high cost of staff training or retraining concerning EE issues }\end{array}$ \\
\hline $\begin{array}{l}\text { Social and } \\
\text { educational }\end{array}$ & $\begin{array}{l}\text { - people's internal resistance to change; } \\
\text { - people's lack of training and understanding of how ES works; } \\
\text { - lack of trust in unfamiliar technology; } \\
\text { - lack of an established corporate culture of ES at the university; } \\
\text { - lack of environmental awareness of university staff and students; } \\
\text { - lack of information data for staff and students about the university energy costs and energy } \\
\text { consumption of purchased equipment; } \\
\text { - lack of information for university staff and students about the expected positive effects of ES } \\
\text { in the university and opportunities and procedures for their participation in the implementation } \\
\text { of EE projects in the educational institution; } \\
\text { - low levels of commitment to ES by university leaders, staff and students }\end{array}$ \\
\hline
\end{tabular}

According to M. Mohammadalizadehkorde and R. Weaver [25], the vast majority of obstacles to EE of universities in countries with emerging and developing economies are not related to technical, but to organizational, economic, financial, and information barriers (Table 1). Often such obstacles are relevant for advanced economies too [19].

Restraints listed in Table 1 are common for many universities in Ukraine, which is a bright example of a country with an emerging economy. The distinguished feature of the state is that barriers from Table 1 are complemented by legal constrains [46], as many domestic higher educational institutions are funded from the state budget. V. M. Shulga and D. S. Khandoga [30] point out that the budget planning system in Ukraine is inadequate to the requirements of increasing efficiency of energy use in universities and significantly limits their ES opportunities, focusing on the implementation of mainly short-term measures and discouraging in an integrated approach to EE. Prolonged and often inefficient tender procedures for procurement of goods and services that do not take into account the EE requirements add to the problems. Thus, we will explore how to overcome the above restraints and ensure the growth of EE of Ukrainian educational institutions, using a case study method on the example of ES policy of SSU.

SSU is one of the higher educational institutions in Ukraine that has its own policy to ensure the EE of the university campus. The latter is part of a comprehensive environmental policy of the institution. In 2019, SSU took second place among Ukrainian universities and 208th position among 790 universities all over the world according to UI GreenMetric World University Ranking [41]. Comparing SSU with the leaders of the rating and three other Ukrainian higher educational institutions - participants in the rating by its components, it is worth noting the highest SSU scores on Energy \& Climate Change among Ukrainian universities (Table 2).

Wageningen University \& Research, the world's leading Waste, Water, Education \& Research and Total Score, loses to the Universita di Bologna in Transportation, Leuphana Universitat Luneburg in Energy \& Climate Change and Bogor Agricultural University in 
Iryna M. Sotnyk, Mykola I. Sotnyk, Alona A. Olondar, Nataliia M. Pidopryhora, Mariana Yu. Maslii. Managing the Energy-Efficient Development of the University: Restraints and Ways to Overcome Them

Setting \& Infrastructure. Among Ukrainian universities, Ukrainian National Forestry University has the highest positions in the ranking for all components, except for Setting \& Infrastructure (the best is Uman National University of Horticulture) and Energy \& Climate Change (the best is SSU). Thus, even the leaders of the world and Ukrainian rankings are not ideal and have the potential for further improvement.

Table 2

Ranking of universities in the world and in Ukraine in UI GreenMetric World University

Ranking 2019 [41]

\begin{tabular}{|c|c|c|c|c|c|c|c|c|}
\hline $\begin{array}{c}\text { World } \\
\text { Ranking }\end{array}$ & University & $\begin{array}{l}\text { Total } \\
\text { Score }\end{array}$ & $\begin{array}{l}\text { Setting \& } \\
\text { Infrastructure }\end{array}$ & $\begin{array}{l}\text { Energy } \\
\& \\
\text { Climate } \\
\text { Change }\end{array}$ & Waste & Water & Transportation & $\begin{array}{c}\text { Education } \\
\& \\
\text { Research }\end{array}$ \\
\hline 1 & $\begin{array}{l}\text { Wageningen } \\
\text { University \& } \\
\text { Research } \\
\text { (Netherland) } \\
\end{array}$ & 9075 & 1125 & 1800 & 1800 & 1000 & 1550 & 1800 \\
\hline 14 & $\begin{array}{l}\text { Universita di } \\
\text { Bologna } \\
\text { (Spain) }\end{array}$ & 8275 & 1100 & 1525 & 1650 & 625 & 1800 & 1575 \\
\hline 36 & $\begin{array}{l}\text { Leuphana } \\
\text { Universitat } \\
\text { Luneburg } \\
\text { (Germany) }\end{array}$ & 7825 & 500 & 2025 & 1725 & 625 & 1400 & 1550 \\
\hline 40 & $\begin{array}{c}\text { Bogor } \\
\text { Agricultural } \\
\text { University } \\
\text { (Indonesia) } \\
\end{array}$ & 7775 & 1400 & 1200 & 1425 & 575 & 1475 & 1700 \\
\hline 111 & $\begin{array}{l}\text { Ukrainian } \\
\text { National } \\
\text { Forestry } \\
\text { University }\end{array}$ & 6900 & 1000 & 1125 & 1050 & 650 & 1275 & 1800 \\
\hline 208 & $\begin{array}{l}\text { Sumy State } \\
\text { University }\end{array}$ & 6050 & 950 & 1450 & 750 & 600 & 1100 & 1200 \\
\hline 409 & $\begin{array}{c}\text { Uman } \\
\text { National } \\
\text { University of } \\
\text { Horticulture } \\
\end{array}$ & 4900 & 1050 & 820 & 600 & 475 & 875 & 1075 \\
\hline 419 & $\begin{array}{c}\text { Poltava } \\
\text { National } \\
\text { Technical Yuri } \\
\text { Kondratyuk } \\
\text { University } \\
\end{array}$ & 4850 & 820 & 650 & 525 & 550 & 1000 & 1300 \\
\hline
\end{tabular}

SSU also has room to grow compared to the achievements of foreign and Ukrainian competitors. At the same time, it is important to provide organizational support and development of the university's achievements in the field of EE. SSU's ES policy has been officially recognized and reflected in the comprehensive target program "Energy efficient SSU", adopted on 13.12.2013 [35]. The purpose of the program was to organize the systematic work of the university staff in the field of energy use to minimize energy costs while maintaining comfortable working conditions. In 2016, the Scientific-research institute of energy-efficient technologies of SSU (SRI ET SSU) was established. Its task is to coordinate the activities of structural units of SSU to conduct comprehensive interdisciplinary research 
І. М. Сотник, М. І. Сотник, А. А. Олондар, Н. М. Підопригора, М. Ю. Маслій.

Управління енергоефективним розвитком університету: бар'єри та шляхи їх подолання

and implementation of scientific and technical projects on EE, non-traditional and renewable energy, the energy impact on the environment and sustainable development issues, popularization and implementation of such research, dissemination of SSU experience in energy management, EE directly in SSU, training of enterprises, organizations and associations of citizens interested in solving problems of EE and ES [36].

As part of its environmental policy [37], in 2019 in the field of ES, SSU has committed to increase the efficiency of electricity and heat, rise the use of renewable energy sources in campus, develop and implement measures to reduce emissions of greenhouse gases caused by the activities of the university. In addition to ES, today the environmental policy of the educational institution considers other components of UI GreenMetric World University Ranking: the transition to the use of environmentally friendly electric vehicles and minimization of harmful environmental impacts of the existing vehicle fleet; expanding the framework of environmental education for students and staff, outsiders, conducting environmental research and development, including in cooperation with state and local authorities, business entities; improving the efficiency of water use, along with increasing the volume of water reuse; reducing waste generation (including hazardous ones) and introducing effective methods of waste management; forming and improving the environmental management system as a component of the general management system of the university, considering environmental aspects in the procurement of products, services, as well as interaction with contractors, etc. [37].

In recent years, the results of SSU's ES activities, led by SRI ET SSU, have been thermal isolation and waterproofing of roofs of buildings and large lecture halls, construction of a solid fuel boiler room for the sports and recreation center "Univer", replacement of windows and heating devices, insulation over $10,000 \mathrm{~m}^{2}$ of facades, installation of mixing pumps in the heating stations of buildings, etc. Due to the implemented engineering and technical measures, scientific developments, elements of energy management, SSU managed to reduce thermal energy consumption by almost $20 \%$, which resulted in significant savings. At the same time, the heating areas were increased and the comfort of working conditions was improved [38].

An essential achievement was the development and distribution of the automated system for monitoring the heat consumption of buildings within the budget sphere of Sumy city, which was created and implemented by SRI ET SSU. This allowed tracking the consumption of energy resources by city budget institutions online and formed conditions for regulating heat consumption to obtain energy savings and improve the comfort of heated premises [38]. SSU has been operating this monitoring system since 2015. It covers 13 heat points of SSU buildings, which are equipped with heat consumption meters. The economic effect of the implementation of the system is about 1.5 million UAH. In 2017-2019, the monitoring system was implemented at 31 objects of the budget sphere of Sumy city, which allowed to achieve $10-12 \%$ savings in thermal energy with a total payback period of up to 1.5 years. In the future, the system can be distributed to 100 facilities located in the Sumy region.

Along with the unconditional successes in saving thermal energy, there are some problems in streamlining electricity consumption in SSU. Table 3 shows data on the use of electricity by housing and educational buildings of the university. As follows from the table, the electricity consumption of residential buildings in SSU is constantly reduced due to ES measures: by $11.54 \%$ in 2017-2019. Although in general for 2017-2019 at SSU campus electricity consumption decreased by $5.63 \%$, the use of electricity by educational buildings significantly increased in 2019 compared to 2018 at both sites. The reasons for this were the rise in educational buildings' area and their energy facilities. Given the modes of operation of educational buildings and the results of research $[1,3,7,14,15,17,48,49]$, there is a 
Iryna M. Sotnyk, Mykola I. Sotnyk, Alona A. Olondar, Nataliia M. Pidopryhora, Mariana Yu. Maslii. Managing the Energy-Efficient Development of the University: Restraints and Ways to Overcome Them

considerable unrealized potential for electricity conservation, which is to minimize the consumption of electricity by educational buildings in the evening and at night, during weekends, holidays, when the educational process is not carried out. In addition, an important reserve for reducing electricity consumption is the formation of a responsible attitude of university staff and students to ES, turning off lights and appliances during their downtime, encouraging procurement by departments and divisions of more energy-efficient machinery and equipment for further use. To motivate employees and students in 2020, a special instruction on setting up ES modes of computer equipment was developed [39].

Table 3

Energy consumption of SSU housing and educational buildings in 2017-2019 (calculated by the authors according to SSU data)

\begin{tabular}{|c|c|c|c|c|c|c|}
\hline \multirow[t]{2}{*}{ Indicator } & \multicolumn{3}{|c|}{ Energy consumption, kWh } & \multicolumn{3}{|c|}{ Energy savings*, $\%$} \\
\hline & 2017 & 2018 & 2019 & $2018 / 2017$ & $\begin{array}{c}2019 / 201 \\
8\end{array}$ & $\begin{array}{c}2019 / 201 \\
7\end{array}$ \\
\hline $\begin{array}{l}\text { Base site of SSU (without } \\
\text { machine-building college), total, } \\
\text { including: }\end{array}$ & 3646627 & 3405007 & 3497324 & $+6,63$ & $-2,71$ & $+4,09$ \\
\hline - housing & 1621004 & 1498118 & 1484360 & $+7,58$ & $+0,92$ & $+8,43$ \\
\hline - educational buildings & 2025623 & 1906889 & 2012964 & $+5,86$ & $-5,56$ & $+0,62$ \\
\hline $\begin{array}{l}\text { Site of the Education and } \\
\text { Research Institute for Business } \\
\text { Technologies "UAB", total, } \\
\text { including: }\end{array}$ & 1803210 & 1668941 & 1645452 & $+7,45$ & $+1,41$ & $+8,75$ \\
\hline - housing & 888631 & 783928 & 735669 & $+11,78$ & $+6,16$ & $+17,21$ \\
\hline - educational buildings & 914579 & 885013 & 909783 & $+3,23$ & $-2,80$ & $+0,52$ \\
\hline $\begin{array}{l}\text { Total on the university campus, } \\
\text { including: }\end{array}$ & 5449837 & 5073948 & 5142776 & $+6,90$ & $-1,36$ & $+5,63$ \\
\hline- housing & 2509635 & 2282046 & 2220029 & $+9,07$ & $+2,72$ & $+11,54$ \\
\hline - educational buildings & 2940202 & 2791902 & 2922747 & $+5,04$ & $-4,69$ & $+0,59$ \\
\hline
\end{tabular}

* "+" - savings, "-" - overconsumption

Much attention of SRI ET SSU is paid to scientific work with students in the field of ES. With that in mind, teachers and students are involved in the implementation of EE projects at the request of enterprises, state and local authorities. This allows strengthening the practical training of future professionals, formation of ES skills, providing interest in learning, revealing intellectual potential, helping to get a job. As a promising area of further work, SRI ET SSU considers the formation of temporary creative teams consisting of research and teaching staff, students and engineers, who have significant professional experience in developing and implementing ES technologies and equipment for innovative research and development projects.

Given the above, it should be noted that today SSU has created the necessary regulatory framework and organizational structures for effective energy management on the university campus and promoting EE development outside it. At the same time, there are various groups of restraints to the further implementation of ES policies, in particular, technical ones, which are closely related to economic and financial barriers. Thus, due to lack of funds, a significant part of the university's office and energy equipment is morally and physically obsolete and does not meet the latest technical standards in terms of EE. The use of renewable energy technologies in the SSU is also hampered by high prices for relevant equipment and, as a result, long payback periods for such projects. The lack of a revolving EE fund at the 
І. М. Сотник, М. І. Сотник, А. А. Олондар, Н. М. Підопригора, М. Ю. Маслій.

Управління енергоефективним розвитком університету: бар'сри та шляхи їх подолання

university considerably slows down the implementation of ES measures, as they currently do not have a clearly defined source of funding. In addition, due to budget constraints, SSU is forced to prefer short-term EE projects over more lucrative long-term ones.

Like other higher educational institutions, SSU faces a number of organizational, social and educational restraints regarding energy conservation. As noted above, lengthy procurement procedures for energy efficient equipment, lack of $\mathrm{EE}$ requirements for the purchase of other goods and services negatively affect the implementation of ES activities at the university. The system of communication with SSU ES stakeholders and their engagement in EE projects needs further improvement. There is still a lack of information from students and faculty about the energy costs of the university campus and individual buildings, equipment, as well as the practical possibilities of ES at the university with the participation of staff and students. Although the environmental awareness of the latter is gradually increasing, many people still have internal resistance to change and disbelief in the positive effects of ES. The system of economic and moral stimulation of ES activity at the university, regulation of energy consumption also requires further improvement.

Based on the analyzed restraints that slow down the energy-efficient development of SSU, it is advisable to propose the following management measures for the systematic realization of the potential for energy consumption rationalization in the university campus:

- creation of a revolving EE fund at the university, which would accumulate funds received from ES, for their further investment in other, larger ES projects. At the expense of such a fund it will be possible to gradually solve the problem of updating morally and physically obsolete university facilities on an energy-efficient basis, to introduce modern renewable energy technologies to ensure the viability of the university;

- introduction and compliance with internal requirements for a high EE level of equipment and other goods and services purchased by the university;

- further development and improvement of the automated monitoring system of heat and electricity consumption at the university with regular acquaintance of the staff and students with energy consumption trends, the possibility of reducing them with the participation of staff and students, encouraging technical personnel to regulate energy consumption based on forecasts generated by the automated monitoring system, introduction of automatic regulation of energy consumption;

- development and implementation of measures to optimize energy consumption (heat and electricity) by the educational buildings of the university, taking into account the modes of their work, further implementation of EE measures in the housing stock;

- timely adjustment of existing and creation of new strategic programs for $\mathrm{EE}$ development of the institution, ensuring their financing and coherence of EE growth goals for different university divisions and departments,

- development of a perfect system of moral and economic incentives for each employee and student to save energy, which is individually interested in achieving EE goals, implementation of relevant strategic and operational plans of the university, support and development of corporate culture of ES at the university;

- popularization of ES activities among students and university staff, other stakeholders by establishing effective communications: coverage of ES aspects in academic disciplines, inservice training programs for teachers and other outsiders, continuation of scientific and technical seminars on ES technologies, Days of sustainable energy, creation of a hotline to advise stakeholders on the possibility and feasibility of implementing EE and renewable energy facilities for consumers, development of SSU-based demonstration zones of EE 
Iryna M. Sotnyk, Mykola I. Sotnyk, Alona A. Olondar, Nataliia M. Pidopryhora, Mariana Yu. Maslii. Managing the Energy-Efficient Development of the University: Restraints and Ways to Overcome Them

technologies and holding information meetings and seminars with potential "consumers" of these technologies;

- expansion of research, including interdisciplinary, on the problems of EE, renewable energy with the involvement of scientists and students of SSU, the implementation of relevant scientific and technical projects at the request of enterprises, local and state authorities, the population.

These measures can be successfully implemented for other Ukrainian universities, ensuring the reduction of their energy consumption and greenhouse gas emissions, helping to strengthen the financial security of institutions and educating a new environmentally conscious generation of Ukrainians.

Conclusions and prospects of further research. A common challenge for all higher educational institutions in the world today is to reduce energy consumption through the introduction of energy-efficient and ES technologies. Universities, especially in countries with emerging and developing economies, often face significant barriers in achieving this goal. These obstacles in emerging and developing economies are partly due to technical constraints. However, most of them belong to the organizational, economic, financial, social and educational ones, as is the case in emerging economies. Lack or inefficient organization of ES activities at the university, deficit of sufficient information on energy consumption and opportunities for personal participation in energy efficient projects of the educational institution lead to contemptuous attitude of staff and students to the realization of its ES potential. As shows the experience of SSU, the organizational role of the initiative team of energy managers, recognition and constant support of the management of energy efficient development of the university, wide involvement of teachers and students in ES activities are extremely important. Without these components, even with the development and funding of ES development programs in higher education, it will be almost impossible to achieve the planned indicators.

Lack of investment and long payback of energy efficient and green energy technologies are also essential obstacles to the introduction of ES. These problems can be solved by creating a revolving EE fund at the university. Promoting the achievements of the educational institution by establishing effective communication with all stakeholders, the formation of a system of moral and economic incentives for ES activities is the key to successful development of energy efficient policy of the educational institution.

The experience of SSU as a case study proves that a systematic approach to the organization of ES activities in the university campus based on the continuous improvement of management mechanisms allows achieving the goals of EE, even with many barriers. At the same time, it should be borne in mind that the set of management measures for building an energy-efficient university depends on the stage of development of ES policy and should be adjusted in the process of EE changes, which may be a direction for further research.

\section{References}

1. Amber, K. P., $\quad$ Aslam, M. W., $\quad$ Mahmood, A. I. D., Kousar, A., $\quad$ Younis, M. Y., Akbar, B., Chaudhary, G. Q., Hussain, S. K. (2017). Energy consumption forecasting for university sector buildings. Energies, 10, 1579. doi: 10.3390/en10101579.

2. Best College Reviews (2020). The 25 best green colleges for 2019. Retrieved from https://www.bestcollegereviews.org/top/green-colleges/.

3. Cotton, D. R. E., Shiel, Ch., Finisterra do Paço, A. M. (2016). Energy saving on campus: A comparison of students' attitudes and reported behaviours in the UK and Portugal. Journal of Cleaner Production, 129. doi: 10.1016/j.jclepro.2016.03.136. 
І. М. Сотник, М. І. Сотник, А. А. Олондар, Н. М. Підопригора, М. Ю. Маслій.

Управління енергоефективним розвитком університету: бар'сри та шляхи їх подолання

4. Degtyarova, I. B., Melnyk, O. I., Romanenko, Ya. V. (2014). Ekonomichni ta finansovi instrumenty zabezpechennya stalogo regional nogo rozvytku: dosvid ES. [Economic and financial instruments for sustainable regional development: the EU experience]. Mekhanizm rehulyuvannya ekonomiky Mechanism of economic regulation, 3, 18-27 [in Ukrainian].

5. Denysyuk, S. P., Borychenko, O. V. (2013). Integrovani systemy energomenedzhmentu yak osnova pobudovy suchasnoyi polityky energoefektyvnosti vyshhyh navchalnyh zakladiv [Integrated energy management systems as a basis for building a modern energy efficiency policy of higher education institutions]. Visnyk KNUTD - Bulletin of KNUTD, 6, 212-220 [in Ukrainian].

6. Deshko, V. I., Shevchenko, O. M. (2013). University campuses energy performance estimation in Ukraine based on measurable approach. Energy and Buildings, 66, 582-590. doi: 10.1016/j.enbuild.2013.07.070.

7. Dong Woo Kim, Jae Woong Jung, Ho Tae Seok, Jeong Hoon Yang (2010). Survey and analysis of energy consumption in university campuses. International Conference on Sustainable Building Asia SB10 Seoul. Retrieved from https://www.irbnet.de/daten/iconda/CIB17386.pdf.

8. Emeakaroha, A., Chee Siang Ang, Yong Yan (2012). Challenges in improving energy efficiency in a university campus through the application of persuasive technology and smart sensors. Challenges, 3(2), 290-318. doi: 10.3390/challe4010017.

9. Sotnyk, I. M. (2019). Energoefektyvnist ta vidnovlyuvalna energetyka v Ukrayini: problem upravlinnya. [Energy efficiency and renewable energy in Ukraine: problems of management]. Sumy, VTD «Universytetska knyha» [in Ukrainian].

10. European Commission (2020). Energy use in buildings. Retrieved from https://ec.europa.eu/energy/eu-buildings-factsheets-topics-tree/energy-use-buildings_en.

11. Fihurka, M. V. (2018). Provedennya energoaudytu zakladiv vyshhoyi osvity v Ukrayini. [Conducting energy audit of higher education institutions in Ukraine]. Podilskyj visnyk: silske gospodarstvo, texnika, ekonomika. Ekonomichni nauky - Journal Podolsky Bulletin: Agriculture, Technology, Economics. Economic Sciences, 29, 196-201 [in Ukrainian].

12. Friendly power (2020). Colleges and Universities. Retrieved from https://esource.bizenergyadvisor.com/article/colleges-and-universities.

13. Gajdukevych, S. V., Semenova, N. P., Solovej, I. M. (2019). Shlyakhy energozberezhennya pry zabezpechenni mikroklimatu uchbovyh prymishhen [Ways of energy saving while ensuring the microclimate of educational premises]. In: Energoefektynist ta energozberezhennya: ekonomichnyj, tehniko-tehnologichny ta ekologichnyj aspekty [Energy efficiency and energy saving: economic, technical, technological and ecological aspects] : collective monograph; (Eds.) P. M. Makarenko, O. V. Kalinichenko, V. I. Aranchij. Poltava : PP "Astraya", 155-166 [in Ukrainian].

14. Jiafang Song, Xuelin Zhang, Xiangquan Meng (2015). Simulation and analysis of a university library energy consumption based on EQUEST. Procedia Engineering, 12, p. 1382-1388. doi: 10.1016/j.proeng.2015.09.028.

15. Jomoah, I. M., Al-Abdulaziz, A. U. M., Kumar, R. S. (2013). Energy management in the buildings of a university campus in Saudi Arabia - A case study. 4th International Conference on Power Engineering, Energy and Electrical Drives, Istanbul, 659-663. doi: 10.1109/PowerEng.2013.6635688.

16. Kurbatova, T. (2018). Economic benefits for producers of biogas from cattle manure within energy co-operatives in Ukraine. International Journal of Sustainable Energy Planning and Management, 18, 69-80. https://doi.org/10.5278/ijsepm.2018.18.5.

17. Li-juan Qu, Li-nan Lei, Wei Chen, Jin-yuan Qian (2015). Energy consumption prediction of university buildings in China and strategies for energy efficiency management. Proceedings of the ASME 2015 Power and Energy Conversion. Conference Power Energy 2015, June 28-July 2, 2015, San Diego, California, 1-6.

18. Lodi, Ch., Malaguti, V., Contini, F. M., Sala, L., Muscio, A., Tartarini, P. (2017). University energy planning for reducing energy consumption and GHG emissions: the case study of a university campus in Italy. International Journal of Heat and Technology, 35(1), S27-S32. doi: 10.18280/ijht.35Sp0104. 
Iryna M. Sotnyk, Mykola I. Sotnyk, Alona A. Olondar, Nataliia M. Pidopryhora, Mariana Yu. Maslii. Managing the Energy-Efficient Development of the University: Restraints and Ways to Overcome Them

19. Maiorano, J., Savan B. (2015). Barriers to energy efficiency and the uptake of green revolving funds in Canadian universities. International Journal of Sustainability in Higher Education, 16, 200-216.

20. Maistry, N., McKay, T. M. (2016). Promoting energy efficiency in a South African university. Journal of Energy in Southern Africa, 27 (3). Retrieved from http://www.scielo.org.za/pdf/jesa/v27n3/01.pdf.

21. Melnyk, L. G., Degtyarova, I. B. (2012). Dosvid Yevropejs`kogo Soyuzu u formuvanni innovacijnoyi strategiyi stalogo rozvytku [The experience of the European Union in shaping an innovative strategy for sustainable development]. Marketyng i menedzhment innovacij - Marketing and Management of Innovations, 1, 190-200 [in Ukrainian].

22. Melnyk, L. G., Melnyk, O.I., Karintseva, O. I. et al. (2007). Konceptual'ni pidhody do zmin modelej spozhyvannya ta vyrobnycztva pry perehodi do stijkogo rozvytku [Conceptual approaches to changes in consumption and production patterns in the transition to sustainable development]. Mekhanizm rehulyuvannya ekonomiky - Mechanism of economic regulation, 3, 51-58 [in Ukrainian].

23. Melnyk, L., Kubatko, O. (2017). The impact of green-innovations on environmental quality and energy resource consumption. In : International economic relations and sustainable development: monograph. (Eds.) O. Prokopenko, T. Kurbatova. Ruda Śląska: Drukarnia i Studio Graficzne Omnidium.

24. Mentel, G., Vasilyeva, T., Samusevych, Y., Pryymenko, S. (2018). Regional differentiation of electricity prices: Social-equitable approach. International Journal of Environmental Technology and Management, 21(5-6), 354-372. https://doi.org/10.1504/IJETM.2018.100583.

25. Mohammadalizadehkorde, M., Weaver, R. (2018). Universities as models of sustainable energyconsuming communities? Review of selected literature. Sustainability, 10, 3250. doi: $10.3390 /$ su10093250.

26. Organizacijno-ekonomichni mekhanizmy stymulyuvannya rozvytku vidnovlyuvalnoyi energetyky Ukrayiny [Organizational and economic mechanisms for stimulating the renewable energy development in Ukraine]. (2017). Zvit pro NDR (promizhnyj) [R\&D report (interim)]. (Ed.) I. M. Sotnyk. Sumy : SumDU [in Ukrainian].

27. Pshinko, O. M., Sychenko, V. G., Kuzneczov, V. G., Yacenko, D. K. (2012). Pidvyshhennya efektyvnosti spozhyvannya elektroenergiyi $\mathrm{v}$ universyteti [Improving the electricity consumption efficiency at the university]. Energozberezhennya. Energetyka. Energoaudyt - Energy saving. Energy. Energy audit, 10 (104), 30-34 [in Ukrainian].

28. Pshinko, O. M., Yacenko, D. K., Kuzneczov, V. G., Shaptala, M. V. (2013). Analiz vprovadzhennya energozberigayuchyh zaxodiv $\mathrm{v}$ universyteti [Analysis of the energy saving measures implementation at the university]. Visnyk KNUTD - Bulletin of KNUTD, 6, 344-352 [in Ukrainian].

29. Safulina, K. R., Koliyenko, A. G., Tormosov, R. Yu. (2010). Energozberezhennya v universytetskyh mistechkah [Energy saving on university campuses]. Kyiv : TOV "Poligraf plyus" [in Ukrainian].

30. Shulga, V. M., Khandoga, D. S. (2016). Pidvyshhennya energoefekty`vnosti vyshhogo navchalnogo zakladu [Energy efficiency improvement of a higher education institution]. Prychornomors $k i$ ekonomichni studiyi - Black Sea Economic Studies, 9-2, 68-71.

31. Sineviciene, L., Kubatko, O., Sotnyk, I., Lakstutiene, A. (2019). Economic and environmental performance of post-communist transition economies. Bilgin M., Danis H., Demir E., Can U. (eds). Eurasian Economic Perspectives. Eurasian Studies in Business and Economics, 11/1. Springer, Cham, 125-141. doi: 10.1007/978-3-030-18565-7_10.

32. Sineviciene, L., Sotnyk, I., Lakstutiene, A., Kubatko, O. (2017). What makes countries to be energy efficient: case of Lithuania and Ukraine? Proceedings of the 2017 International Conference "Economic Science for Rural Development" № 45. Jelgava, LLU ESAF, 27-28 April 2017, 213-220.

33. Sotnyk, I., Dehtyarova, I., Kovalenko, Y. (2015). Current threats to energy and resource efficient development of Ukrainian economy. Actual Problems of Economics, 11, 137-145.

34. Sotnyk, I. M. (2010). Upravlinnya resursozberezhennyam: socio-ekologo-ekonomichni aspekty. [Resource saving management: socio-ecological and economic aspects]. Sumy : Vydavnytstvo SumDU [in Ukrainian]. 
І. М. Сотник, М. І. Сотник, А. А. Олондар, Н. М. Підопригора, М. Ю. Маслій.

Управління енергоефективним розвитком університету: бар'сри та шляхи їх подолання

35. SSU (2013). Kompleksna cilova programa "Energoefektyvnyj SumDU". [Comprehensive target program "Energy Efficient SSU"]: the order from 19.12.2013, № 1033-I. Retrieved from https://normative.sumdu.edu.ua/?task=getfile\&tmpl=component\&id=90af0426-1a7d-e311-b59a001a4be6d04a\&kind=1 [in Ukrainian].

36. SSU (2016). Polozhennya pro naukovo-doslidnyj instytut energoefektyvnyh tehnologij SumDU. [Regulations on Scientific-research Institute of Energy Efficient Technologies of SSU]: the order from 31.08.2016, № $\quad$ 0522-I. $\quad$ Retrieved from https://normative.sumdu.edu.ua/?task=getfile\&tmpl=component\&id=28d6d293-4270-e611-a40c001a4be6d04a\&kind=1 [in Ukrainian].

37. SSU (2019). Ekologichna polityka Sumskogo derzhavnogo universytetu. [Environmental policy of Sumy State University]: the order from 13.12.2019, № 0912-I. Retrieved from https://normative.sumdu.edu.ua/?task=getfile \&tmpl=component\&id=549d1662-b91d-ea11-945a001a4be6d04a\&kind=1 [in Ukrainian].

38. SSU (2020). Energoefektyvnyj universytet [Energy efficient university]. Retrieved from https://sumdu.edu.ua/uk/about-sumdu/korysni-posylannia/green-university/energy-efficientuniversity.html [in Ukrainian].

39. SSU (2020). Instrukciya pro nalashtuvannya energozberigayuchyh rezhymiv roboty kompyuternoyi tehniky [Instruction on setting energy-saving modes of computer equipment]: the order from 22.05.2020, № $\quad 0008 . \quad$ Retrieved from https://normative.sumdu.edu.ua/?task=getfile\&tmpl=component\&id=ac3b0a6d-14a0-ea11-95dad4856459ca35\&kind $=1$ [in Ukrainian].

40. Sun, L. Content and low-carbon path in university campus (2011). Business and Economy, 11, 1517.

41. UI GreenMetric (2020). UI GreenMetric World University Ranking 2019. Retrieved from http://greenmetric.ui.ac.id/overall-rankings-2019/.

42. UMass Amherst (2020). Energy efficiency. Retrieved from https://www.umass.edu/sustainability/climate-change-energy/energy-efficiency.

43. UNEP (2013). Greening Universities Toolkit. Transforming universities into green and sustainable campuses: A toolkit for implementers. Retrieved from http://wedocs.unep.org/bitstream/handle/20.500.11822/11273/Greening_unis_toolkit_Single_Page.p df? sequence $=1 \&$ isAllowed $=y$.

44. UNEP (2014). Greening Universities Toolkit V2.0. Transforming universities into green and sustainable campuses: A toolkit for implementers. Retrieved from http://wedocs.unep.org/bitstream/handle/20.500.11822/11964/Greening\%20University\%20Toolkit\% 20V2.0.pdf? sequence $=1$ \&isAllowed $=y$.

45. USAID Project "Municipal Energy Reform in Ukraine" (MER) (2015). Analitychna dovidka. Systemy monitoryngu spozhyvannya energoresursiv $\mathrm{v}$ byudzhetnyh zakladax ukrayinskyh mist. [Analytical reference. Energy consumption monitoring systems in budget institutions of Ukrainian cities]. Retrieved from https://aea.org.ua/wp-content/uploads/Analitichnadovidka_energomonitoring_AEA_USAID.pdf [in Ukrainian].

46. Verkhovna Rada of Ukraine (2015). Budget Code of Ukraine from 20.09.2015, No. 2456-VI Retrieved from https://zakon.rada.gov.ua/laws/show/2456-17/ed20150920?lang=en\#Text.

47. Wageningen University \& Research (2020). Sustainability. Retrieved from https://www.wur.nl/en/About-Wageningen/Sustainability.htm.

48. Ying Han, Xuejie Zhou, Ruijiang Luo (2015). Analysis on campus energy consumption and energy saving measures in cold region of China. Procedia Engineering, 121, 801-808.

49. Zhou, X., Yan, J., Zhu, J., et al. (2013). Survey of energy consumption and energy conservation measures for colleges and universities in Guangdong province. Energy and Buildings, 66, 112-118.

Manuscript received 12 August 2020 
Iryna M. Sotnyk, Mykola I. Sotnyk, Alona A. Olondar, Nataliia M. Pidopryhora, Mariana Yu. Maslii. Managing the Energy-Efficient Development of the University: Restraints and Ways to Overcome Them

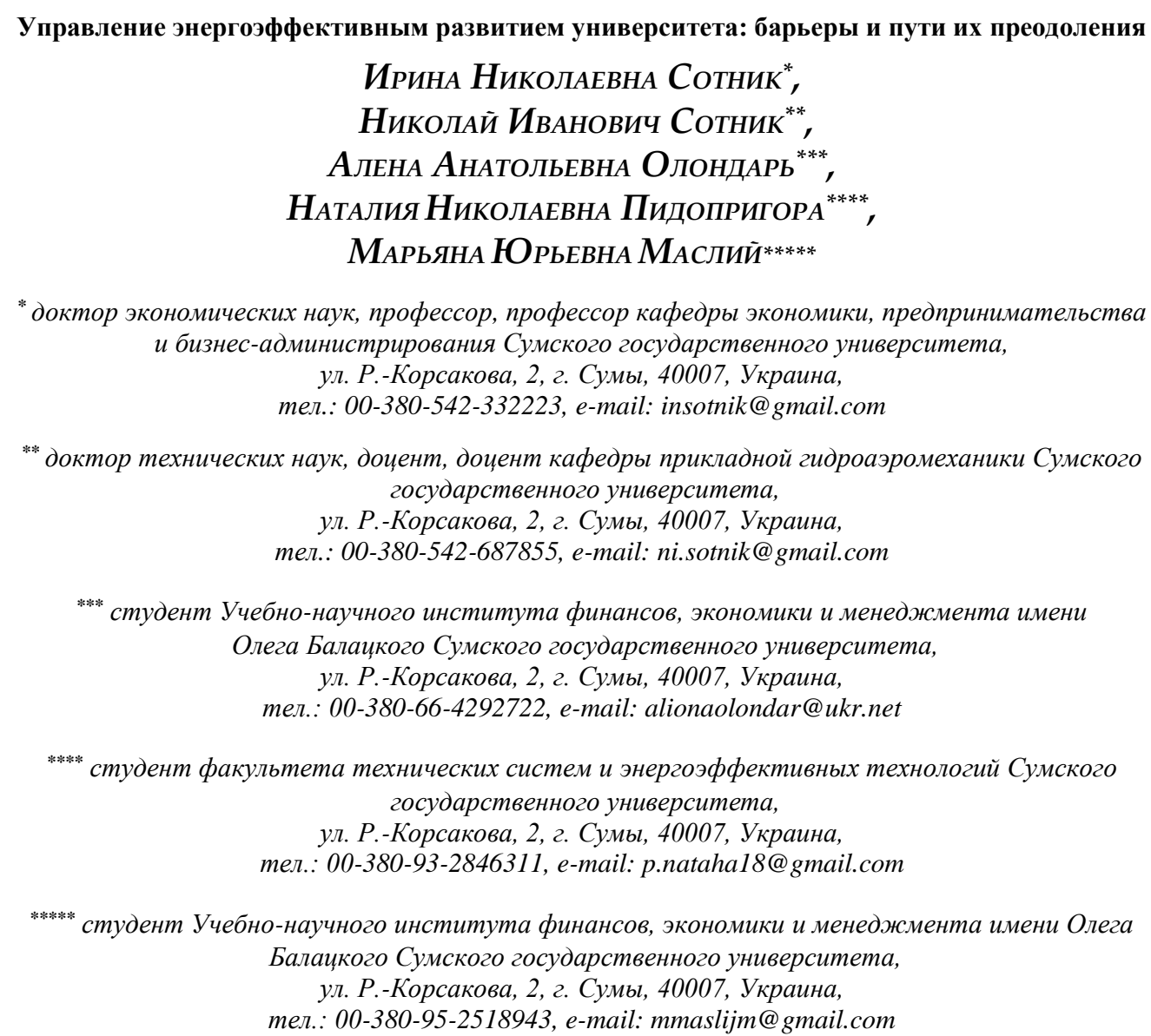

* доктор экономических наук, профессор, профессор кафедры экономики, предпринимательства и бизнес-администрирования Сумского государственного университета,

ул. Р.-Корсакова, 2, г. Сумыл, 40007, Украина, тел.:00-380-542-332223, e-mail: insotnik@gmail.com

** доктор технических наук, дочент, дочент кафедры прикладной гидроаэромеханики Сумского государственного университета

ул. Р.-Корсакова, 2, г. Сумы, 40007, Украина,

тел.:00-380-542-687855, e-mail: ni.sotnik@gmail.com

**** студент Учебно-научного института финансов, экономики и менеджмента имени

Олега Балачкого Сумского государственного университета,

ул. Р.-Корсакова, 2, г. Сумы, 40007, Украина

тел.:00-380-66-4292722, e-mail: alionaolondar@ukr.net

***** студент факультета технических систем и энергоэффективных технологий Сумского

государственного университета

ул. Р.-Корсакова, 2, г. Сумы, 40007, Украина,

тел.: 00-380-93-2846311,e-mail: p.nataha18@gmail.com

*****: студент Учебно-научного института финансов, экономики и менеджмента имени Олега

Балачкого Сумского государственного университета,

ул. Р.-Корсакова, 2, г. Сумыл, 40007, Украина,

тел.: 00-380-95-2518943,e-mail:mmaslijm@gmail.com

Проблема сокращения энергопотребления путем внедрения энергоэффективных технологий сегодня стоит перед всеми университетами мира. Высшие учебные заведения, особенно в развивающихся странах и с транзитивной экономикой, часто сталкиваются со значительными барьерами при достижении этой цели. В развивающихся государствах эти препятствия частично связаны с техническими ограничениями. Однако большинство из них принадлежат именно к организационным, экономико-финансовым, социальным и образовательным, как это имеет место в транзитивных экономиках. Сложившаяся ситуация актуализирует вопросы идентификации барьеров энергосбережению в университетских кампусах и формирования комплекса организационно-экономических и мотивационных мероприятий по системной реализации потенциала энергосбережения в высших учебных заведениях. Результаты исследования на примере Сумского государственного университета (Украина) подтверждают критическую роль инициативной команды энергоменеджеров, необходимость признания и постоянной поддержки руководством энергоэффективного развития университета, широкого привлечения преподавателей и студентов к энергосберегающей деятельности. Создание воспроизводственного фонда энергоэффективности в университете может помочь преодолеть нехватку инвестиций и проблему длительной окупаемости энергоэффективных и «зеленых» энерготехнологий. Кроме того, популяризация достижений учебного заведения в сфере энергосбережения путем налаживания эффективной коммуникации со всеми стейкхолдерами, формирование системы морального и экономического стимулирования энергосберегающей деятельности будет активно 
І. М. Сотник, М. І. Сотник, А. А. Олондар, Н. М. Підопригора, М. Ю. Маслій.

Управління енергоефективним розвитком університету: бар'єри та шляхи їх подолання

содействовать успешному развитию энергоэффективной политики университета.

Ключевые слова: барьеры, энергопотребление, энергосбережение, энергоэффективность, управление, политика, устойчивое развитие, университет.

\author{
Mechanism of Economic Regulation, 2020, No 3, 68-86 \\ ISSN 1726-8699 (print)
}

Управління енергоефективним розвитком університету: бар'єри та шляхи їх подолання

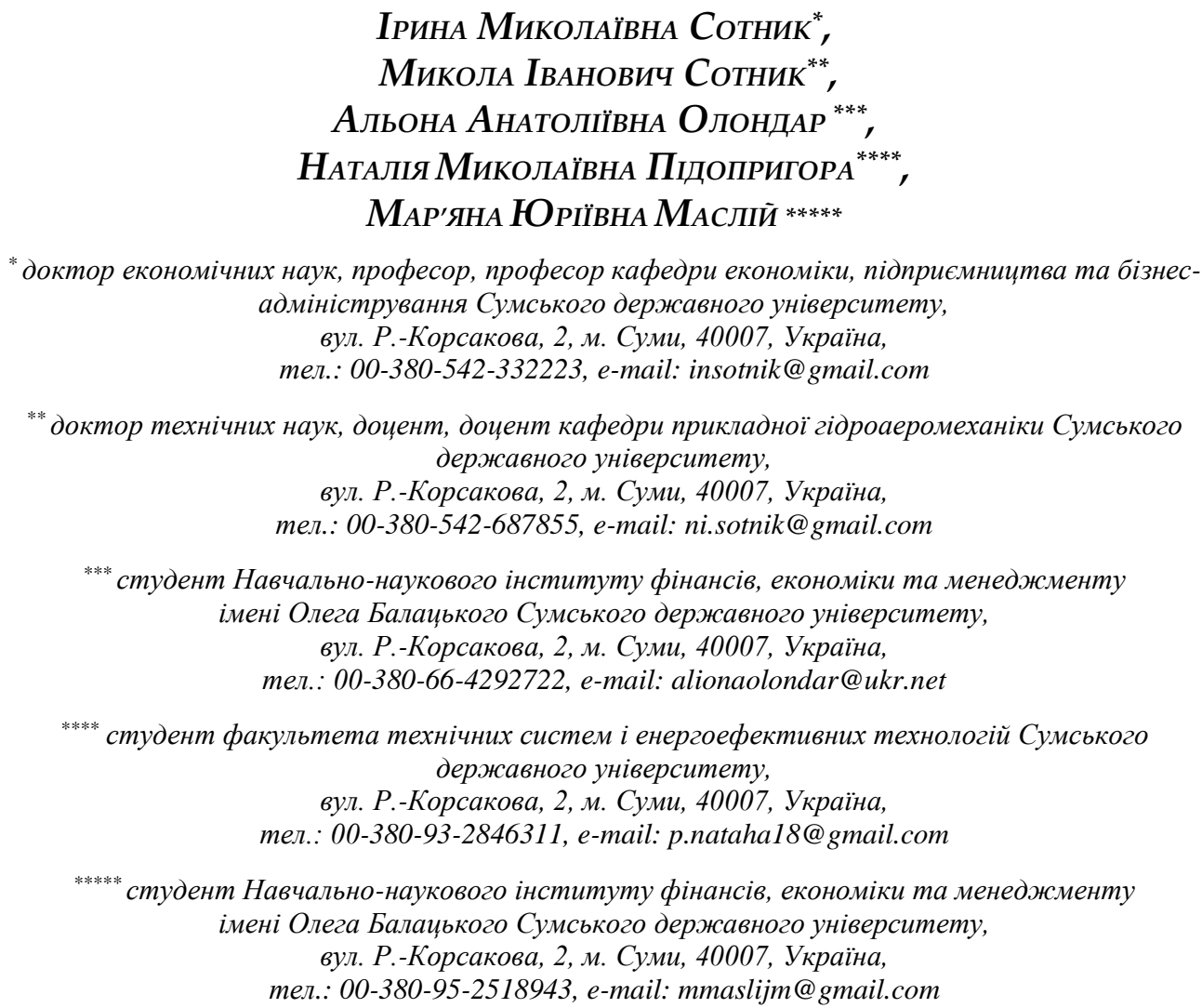

* доктор економічних наук, професор, професор кафедри економіки, підприємництва та бізнесадміністрування Сумського державного університету, вул. Р.-Корсакова, 2, м. Суми, 40007, Украӥна, тел.:00-380-542-332223, e-mail: insotnik@gmail.com

***октор технічних наук, дочент, доцент кафедри прикладної гідроаеромеханіки Сумського державного університету,

вул. Р.-Корсакова, 2, м. Суми, 40007, Україна, тел.:00-380-542-687855,e-mail:ni.sotnik@gmail.com

*** студент Навчально-наукового інституту фінансів, економіки та менеджменту імені Олега Балачького Сумського державного університету,

вул. Р.-Корсакова, 2, м. Суми, 40007, Україна, тел.:00-380-66-4292722,e-mail: alionaolondar@ukr.net

Проблема скорочення енергоспоживання шляхом запровадження енергоефективних технологій сьогодні стоїть перед усіма університетами світу. Заклади вищої освіти, особливо в країнах, що розвиваються, та 3 транзитивною економікою, часто стикаються зі значними бар'єрами при досягненні цієї мети. Частково ці перешкоди у держав, що розвиваються, пов’язані 3 технічними обмеженнями. Проте більшість з них належать саме до організаційних, економікофінансових, соціальних та освітніх, як це має місце в транзитивних економіках. Ця ситуація актуалізує питання ідентифікації бар'єрів енергозбереженню в університетських кампусах i формування комплексу організаційно-економічних та мотиваційних заходів щодо системної реалізації потенціалу енергозбереження у закладах вищої освіти. Результати дослідження на прикладі Сумського державного університету (Україна) підтверджують вирішальну роль ініціативної команди енергоменеджерів, необхідність визнання і постійної підтримки керівництвом енергоефективного розвитку університету, широкого залучення викладачів $і$ студентів до енергозберігаючої діяльності. Створення відтворювального фонду 
Iryna M. Sotnyk, Mykola I. Sotnyk, Alona A. Olondar, Nataliia M. Pidopryhora, Mariana Yu. Maslii. Managing the Energy-Efficient Development of the University: Restraints and Ways to Overcome Them

енергоефективності в університеті може суттво допомогти подолати брак інвестицій та проблему тривалої окупності енергоефективних та «зелених» енерготехнологій. Крім того, популяризація досягнень закладу освіти з енергозбереження шляхом налагодження ефективної комунікації 3 усіма стейкхолдерами, формування системи морального та економічного стимулювання до енергозберігаючої діяльності активно спряє успішній розбудові енергоефективної політики університету.

Ключові слова: бар'єри, енергоспоживання, енергозбереження, енергоефективність, управління, політика, сталий розвиток, університет.

JEL Codes: I25, O13, Q20, Q55

Tables: 3; References: 49

Language of the article: English

Лimepamypa

1. Amber, K. P. Energy consumption forecasting for university sector buildings / K. P. Amber, M. W. Aslam, A. I. D. Mahmood, A. Kousar, M. Y. Younis, B. Akbar, G. Q. Chaudhary, S. K. Hussain // Energies. 2017. - № 10. - C. 1579. doi: 10.3390/en10101579.

2. The 25 best green colleges for 2019 [Електронний ресурс] / Best College Reviews, 2020. - Режим доступу : https://www.bestcollegereviews.org/top/green-colleges/.

3. Cotton, D. R. E. Energy saving on campus: A comparison of students' attitudes and reported behaviours in the UK and Portugal / D. R. E. Cotton, Ch. Shiel, A. M. Finisterra do Paço // Journal of Cleaner Production. 2016. - № 129. doi: 10.1016/j.jclepro.2016.03.136.

4. Дегтярьова, І. Б. Економічні та фінансові інструменти забезпечення сталого регіонального розвитку: досвід ЄС / І. Б. Дегтярьова, О. І. Мельник, Я. В. Романенко // Механізм регулювання економіки. 2014. - № 3. - С. 18-27.

5. Денисюк, С.П. Інтегровані системи енергоменеджменту як основа побудови сучасної політики енергоефективності вищих навчальних закладів / С. П. Денисюк, О. В. Бориченко // Вісник КНУТД. - 2013. - № 6. - С. 212-220.

6. Deshko, V. I. University campuses energy performance estimation in Ukraine based on measurable approach / V. I. Deshko, O. M. Shevchenko // Energy and Buildings. 2013. - № 66. - C. 582-590. doi: https://doi.org/10.1016/j.enbuild.2013.07.070.

7. Dong Woo Kim. Survey and analysis of energy consumption in university campuses [Електронний pecypc] / Dong Woo Kim, Jae Woong Jung, Ho Tae Seok, Jeong Hoon Yang // International Conference on Sustainable Building Asia SB10 Seoul, 2010. - Режим доступу : https://www.irbnet.de/daten/iconda/CIB17386.pdf.

8. Emeakaroha, A. Challenges in improving energy efficiency in a university campus through the application of persuasive technology and smart sensors / A. Emeakaroha, Chee Siang Ang, Yong Yan // Challenges. 2012. - № 3(2). - C. 290-318. doi: 10.3390/challe4010017.

9. Енергоефективність та відновлювальна енергетика в Україні: проблеми управління : монографія / за заг. ред. І. М. Сотник. - Суми: ПФ «Видавництво «Університетська книга», 2019. $-247 \mathrm{c}$.

10. Energy use in buildings [Електронний ресурс] / European Commission, 2020. - Режим доступу : https://ec.europa.eu/energy/eu-buildings-factsheets-topics-tree/energy-use-buildings_en.

11. Фігурка, М. В. Проведення енергоаудиту закладів вищої освіти в Україні / М. В. Фігурка // Подільський вісник: сільське господарство, техніка, економіка. Економічні науки. - 2018. Вип. 29. - С. 196-201.

12. Colleges and Universities [Електронний pecypc] / Friendly power, 2020. - Режим доступу : https://esource.bizenergyadvisor.com/article/colleges-and-universities.

13. Гайдукевич, C. B. Шляхи енергозбереження при забезпеченні мікроклімату учбових приміщень / С. В. Гайдукевич, Н. П. Семенова, І. М. Соловей // Енергоефективність та енергозбереження: економічний, техніко-технологічний та екологічний аспекти : колективна монографія / кол. авторів; за заг. ред. П. М. Макаренка, О. В. Калініченка, В. І. Аранчій. Полтава : ПП «Астрая», 2019. - С. 155-166. 
І. М. Сотник, М. І. Сотник, А. А. Олондар, Н. М. Підопригора, М. Ю. Маслій.

Управління енергоефективним розвитком університету: бар'сри та шляхи їх подолання

14. Jiafang Song. Simulation and analysis of a university library energy consumption based on EQUEST / Jiafang Song, Xuelin Zhang, Xiangquan Meng // Procedia Engineering. 2015. - № 12. - C. 1382 1388. doi: 10.1016/j.proeng.2015.09.028.

15. Jomoah, I. M. Energy management in the buildings of a university campus in Saudi Arabia - A case study / I. M. Jomoah, A. U. M. Al-Abdulaziz, R. S. Kumar // 4th International Conference on Power Engineering, Energy and Electrical Drives. - Istanbul, 2013. - C. 659-663. doi:10.1109/PowerEng.2013.6635688.

16. Kurbatova, T. Economic benefits for producers of biogas from cattle manure within energy cooperatives in Ukraine / T. Kurbatova // International Journal of Sustainable Energy Planning and Management. 2018. - № 18. - C. 69-80. https://doi.org/10.5278/ijsepm.2018.18.5.

17. Li-juan $Q u$. Energy consumption prediction of university buildings in China and strategies for energy efficiency management / Li-juan Qu, Li-nan Lei, Wei Chen, Jin-yuan Qian // Proceedings of the ASME 2015 Power and Energy Conversion. Conference PowerEnergy2015, June 28 - July 2, 2015, San Diego, California. - C. 1-6.

18. Lodi, Ch. University energy planning for reducing energy consumption and GHG emissions: the case study of a university campus in Italy / Ch. Lodi, V. Malaguti, F. M. Contini, L. Sala, A. Muscio, P. Tartarini // International Journal of Heat and Technology. 2017. - № 35(1). - C. S27-S32. doi: 10.18280/ijht.35Sp0104.

19. Maiorano, $J$. Barriers to energy efficiency and the uptake of green revolving funds in Canadian universities / J. Maiorano, B. Savan // International Journal of Sustainability in Higher Education. 2015. - № 16. - C. 200-216.

20. Maistry, N. Promoting energy efficiency in a South African university [Електронний ресурс] / N. Maistry, T. M. McKay // Journal of Energy in Southern Africa. 2016. - № 27 (3). - Режим доступу : http://www.scielo.org.za/pdf/jesa/v27n3/01.pdf.

21. Мельник, Л. Г. Досвід Європейського Союзу у формуванні інноваційної стратегії сталого розвитку / Л. Г. Мельник, І. Б. Дегтярьова // Маркетинг і менеджмент інновацій. 2012. - № 1. C. $190-200$.

22. Мельник, Л. Г. Концептуальні підходи до змін моделей споживання та виробництва при переході до стійкого розвитку / Л. Г. Мельник, О. І. Мельник, О. І. Карінцева та ін. // Механізм регулювання економіки. 2007. - № 3. - С. 51-58.

23.Melnyk, L. The impact of green innovations on environmental quality and energy resource consumption / L. Melnyk, O. Kubatko // International economic relations and sustainable development : monograph / edited by O. Prokopenko, T. Kurbatova. - Ruda Śląska : Drukarnia i Studio Graficzne Omnidium, 2017. - 272 c.

24. Mentel, G. Regional differentiation of electricity prices: Social-equitable approach / G. Mentel, T. Vasilyeva, Y. Samusevych, S. Pryymenko // International Journal of Environmental Technology and Management. 2018. - № 21(5-6). - C. 354-372. doi: 10.1504/IJETM.2018.100583.

25. Mohammadalizadehkorde, $M$. Universities as models of sustainable energy-consuming communities? Review of selected literature / M. Mohammadalizadehkorde, R. Weaver // Sustainability. 2018. - № 10. - C. 3250. doi: 10.3390/su10093250.

26. Організаційно-економічні механізми стимулювання розвитку відновлювальної енергетики України : звіт про НДР (проміжний) / кер. І. М. Сотник. - Суми : СумДУ, 2017. - 110 с.

27. Пшінько, О. М. Підвищення ефективності споживання електроенергії в університеті / О. М. Пшінько, В. Г. Сиченко, В. Г. Кузнецов, Д. К. Яценко // Енергозбереження. Енергетика. Енергоаудит. 2012. - № 10 (104). - С. 30-34.

28. Пшінько, О. М. Аналіз впровадження енергозберігаючих заходів в університеті / О. М. Пшінько, Д. К. Яценко, В. Г. Кузнецов, М. В. Шаптала // Вісник КНУТД. 2013. - № 6. C. $344-352$.

29. Сафуліна, К. Р. Енергозбереження в університетських містечках: посіб. / К. Р. Сафуліна, А. Г. Колієнко, Р. Ю. Тормосов. - К. : ТОВ «Поліграф плюс», 2010. -328 с.

30. Шульга, В. М. Підвищення енергоефективності вищого навчального закладу / В. М. Шульга, Д. С. Хандога // Причорноморські економічні студії. 2016. - Вип. 9-2. - С. 68-71. 
Iryna M. Sotnyk, Mykola I. Sotnyk, Alona A. Olondar, Nataliia M. Pidopryhora, Mariana Yu. Maslii. Managing the Energy-Efficient Development of the University: Restraints and Ways to Overcome Them

31. Sineviciene, L. Economic and environmental performance of post-communist transition economies / L. Sineviciene, O. Kubatko, I. Sotnyk, A. Lakstutiene // Eurasian Economic Perspectives. Eurasian Studies in Business and Economics; Bilgin M., Danis H., Demir E., Can U. (eds). - Springer, Cham, 2019. - № 11/1. - C. 125-141. doi: 10.1007/978-3-030-18565-7_10.

32. Sineviciene, $L$. What makes countries to be energy efficient: case of Lithuania and Ukraine? / L. Sineviciene, I. Sotnyk, A. Lakstutiene, O. Kubatko // Proceedings of the 2017 International Conference «Economic Science for Rural Development», № 45. Jelgava, LLU ESAF, 27-28 April 2017. - C. 213-220.

33. Sotnyk, I. Current threats to energy and resource efficient development of Ukrainian economy / I. Sotnyk, I. Dehtyarova, Y. Kovalenko // Actual Problems of Economics. 2015. - № 11. - C. 137145.

34. Сотник, I. M. Управління ресурсозбереженням: соціо-еколого-економічні аспекти: монографія / І. М. Сотник. - Суми : Вид-во СумДУ, 2010. - 499 с.

35. Комплексна цільова програма «Енергоефективний СумДУ» : наказ від 19.12.2013 p., № 1033-I [Електронний ресурс] / СумДУ, 2013. - Режим доступу : https://normative.sumdu.edu.ua/?task=getfile \&tmpl=component $\&$ id=90af0426-1a7d-e311-b59a001a4be6d04a\&kind $=1$.

36. Положення про науково-дослідний інститут енергоефективних технологій СумДУ : наказ від 31.08.2016 p., № 0522-І [Електронний ресурс] / СумДУ, 2016. - Режим доступу : https://normative.sumdu.edu.ua/?task=getfile \&tmpl=component\&id=28d6d293-4270-e611-a40c001a4be6d04a\&kind=1.

37. Екологічна політика Сумського державного університету : наказ від 13.12.2019 p., № 0912-I [Електронний ресурс] / СумДУ, 2019. - Режим доступу : https://normative.sumdu.edu.ua/?task=getfile \&tmpl=component\&id=549d1662-b91d-ea11-945a001a4be6d04a\&kind $=1$.

38. Енергоефективний університет [Електронний ресурс] / СумДУ, 2020. - Режим доступу : https://sumdu.edu.ua/uk/about-sumdu/korysni-posylannia/green-university/energy-efficientuniversity.html.

39. Інструкиія про налаштування енергозберігаючих режимів роботи комп`ютерної техніки: розпорядження від 22.05.2020р., № 0008p. [Електронний ресурс] / СумДУ, 2020. - Режим доступу : https://normative.sumdu.edu.ua/?task=getfile\&tmpl=component\&id=ac3b0a6d-14a0ea11-95da-d4856459ca35\&kind $=1$.

40. Sun, L. Content and low-carbon path in university campus / L. Sun // Business and Economy. 2011. № 11. - C. 15-17.

41. UI GreenMetric World University Ranking 2019 [Електронний ресурс] / UI GreenMetric, 2020. Режим доступу : http://greenmetric.ui.ac.id/overall-rankings-2019/.

42. Energy efficiency [Електронний pecypc] / UMass Amhers, 2020. - Режим доступу : https://www.umass.edu/sustainability/climate-change-energy/energy-efficiency.

43. Greening Universities Toolkit. Transforming universities into green and sustainable campuses: A toolkit for implementers [Електронний pecypc] / UNEP, 2013. - Режим доступу : http://wedocs.unep.org/bitstream/handle/20.500.11822/11273/Greening_unis_toolkit_Single_Page.p df? sequence $=1$ \&isAllowed $=\mathrm{y}$.

44. Greening Universities Toolkit V2.0. Transforming universities into green and sustainable campuses: A toolkit for implementers [Електронний pecypc] / UNEP, 2014. - Режим доступу : http://wedocs.unep.org/bitstream/handle/20.500.11822/11964/Greening\%20University\%20Toolkit\% 20V2.0.pdf?sequence $=1$ \&isAllowed $=\mathrm{y}$.

45. Аналітична довідка. Системи моніторингу споживання енергоресурсів в бюджетних закладах українських міст [Електронний ресурс] / Проект USAID «Муніципальна енергетична реформа в Україні» (МЕР), 2015. - Режим доступу : https://aea.org.ua/wp-content/uploads/Analitichnadovidka_energomonitoring_AEA_USAID.pdf. 
І. М. Сотник, М. І. Сотник, А. А. Олондар, Н. М. Підопригора, М. Ю. Маслій.

Управління енергоефективним розвитком університету: бар'сри та шляхи їх подолання

46. Бюджетний Кодекс України від 20.09.2015 р., № 2456-VI [Електронний ресурс] / Верховна рада України, 2015. - Режим доступу : https://zakon.rada.gov.ua/laws/show/245617/ed20150920?lang=en\#Text.

47. Sustainability [Електронний ресурс] / Wageningen University \& Research, 2020. - Режим доступу : https://www.wur.nl/en/About-Wageningen/Sustainability.htm.

48. Ying Han. Analysis on campus energy consumption and energy saving measures in cold region of China / Ying Han, Xuejie Zhou, Ruijiang Luo // Procedia Engineering. 2015. - № 121. - C. 801808 .

49. Zhou, X. Survey of energy consumption and energy conservation measures for colleges and universities in Guangdong province / X. Zhou, J. Yan, J. Zhu, et al. // Energy and Buildings. 2013. № 66. - C. 112-118. 